\title{
TIME TO TRACK ENDEMIC DISEASES: EXTRAORDINARY OCCURRENCE DISEASES SHRINKAGE, POLICY, AND ITS RESOURCES MANAGEMENT (2000-2018) IN INDONESIA
}

\author{
SAATNYA MELACAK PENYAKIT ENDEMIK: PENYUSUTAN PENYAKIT LUAR BIASA, \\ KEBIJAKAN, DAN PENGELOLAAN SUMBERDAYA (2000-2018) DI INDONESIA
}

\author{
Al Fauzi Rahmat ${ }^{1}$ \\ ${ }^{1}$ Universitas Muhammadiyah Yogyakarta
}

\begin{abstract}
During 2000-2018 various disease outbreaks (extraordinary occurrences) continued to occur in Indonesia. Its endemic disease outbreak has fluctuated with other endemic, both infectious and non-communicable diseases. This epidemic's vulnerability gives concern for the government to try to deal with various outbreaks that hit Indonesian citizens. This paper aims to review and analyze frequent outbreaks and the extent of the Indonesian government's in tackling disease outbreaks - including policies and its health resources. By analyzing the successes and failures of policies that have occurred, our findings conclude that adequate governance is needed in dealing with disease outbreaks -including Diarrhea, DFH, and Measles. Therefore, the government's key concern is the need for new policies alternative in dealing with disease outbreaks (in cases; Diarrhea, $\mathrm{DFH}$, and Measles), health budget ability, equitable development of health facilities, and equal medical distribution personnel.
\end{abstract}

Keywords: Endemic Disease; Extraordinary Occurrence; Policy; Indonesia.

\begin{abstract}
ABSTRAK
Selama tahun 2000-2018 berbagai wabah penyakit (kejadian luar biasa) terus terjadi di Indonesia. Wabah penyakit endemiknya berfluktuasi dengan endemik lainnya, baik penyakit menular maupun tidak menular. Kerentanan wabah ini memberikan perhatian bagi pemerintah untuk berupaya menangani berbagai wabah yang melanda warga negara Indonesia. Penelitian ini bertujuan untuk meninjau dan menganalisis wabah yang sering terjadi dan sejauh mana pemerintah Indonesia dalam menangani wabah penyakit - termasuk kebijakan dan sumber daya kesehatannya. Dengan menganalisis keberhasilan dan kegagalan kebijakan yang telah terjadi, temuan kami menyimpulkan bahwa diperlukan tata kelola yang memadai dalam menangani wabah penyakit -termasuk Diare, DFH, dan Campak. Oleh karena itu, perhatian utama pemerintah adalah perlunya alternatif kebijakan baru dalam penanganan KLB penyakit (kasus Diare, DBD, dan Campak), kemampuan anggaran kesehatan, pemerataan pembangunan fasilitas kesehatan, dan pemerataan tenaga medis.
\end{abstract}

Kata kunci: Penyakit Endemik; Kejadian Luar Biasa; Kebijakan; Indonesia.

\section{INTRODUCTION}

Indonesia is the fourth most populous country in the world, with a population of around 267.6 million in 2018 and an average population density of 151 per km2 (Worldometers, 2020). It is estimated that the number of population and population density will continue to experience a massive increase in the next few years, as reported in the prediction report on Indonesia's population for 2010-2035 (Jones, 2014). Given increasing the number of population and population density, it is closely related to the increase in the amount of waste produced and it is need for sanitation.

Based on the Central Statistics Agency Report (2018), Indonesia still has an alarming and concerning report in terms of sanitation. Access to sanitation was $67.80 \%$ in 2016 , then $67.89 \%$ in 2017 , and increased again to $69.27 \%$ in 2018 . Poor sanitation is one factor in the increasing number of disease vector cases - including infectious diseases (Jong et al., 2018). We argue that poor sanitation and expanding residential density as well as lousy behavior towards environmental conditions. All of these things pose a significant threat to the emergence of some infectious diseases. It is emphasized more sharply that poor sanitation will cause death rates in children due to diarrheal (Arlinda, 2019). Likewise, poor sanitation is also very closely related to DHF. Poor sanitation is the cause of the high number of DHF vector density. It results in high cases of sufferers (Arsyad, Nabuasa, \& Ndoen, 2020; Pertiwi, Mirnawati, Laila, \& Putra, 2019). On the other hand, the density of occupancy coupled with poor environmental conditions (i.e., inadequate sanitation) can increase the risk of spreading infectious diseases such as measles (Isidore, 2011). In short, of the three types of diseases mentioned above are endemic diseases -including extraordinary occurrences disease that are often experienced by Indonesian people (Palang Merah Indonesia, 2015).

From several past studies in the last decade, many researchers have studied extraordinary occurrences (KLB) disease in Indonesia including Diarrhea, DFH, and Measles with various 
background topics in certain fields. However, we found something missing about the previous study, namely the year to year management policy for the three diseases. Therefore, this paper is positioned to complement the previous missing studies. This article provides a brief overview of three primary health issues. Besides, it analyzes the existing literature regarding the availability of health policies related to three major health issues, health finance, $\mathrm{HR}$ in the health sector, and health facilities.

\section{METHOD}

To initiate findings and discussions, we used a qualitative method with a case study approach. Qualitative case studies are an approach that facilitates researchers to explore a phenomenon using multiple data sources (Baxter, Susan Jack, \& Jack, 2008). Therefore, qualitative case study research can be viewed from its function as exploratory research to address how they describe new phenomena by tracing their surroundings (Ridder, 2017). However, qualitative research with a case study approach allows the researcher to study complex observed phenomena and then conceptualize them.

Then, the data collection technique in this research uses literature studies, by reviewing various documents related to the case being studied, namely the extraordinary occurrence of diarrhea, dengue fever, and a measles. Health report documents from the Health Ministry of the Republic of Indonesia and documents on endemic diseases are essential in describing various policy efforts to control extraordinary occurrence in Indonesia. Besides, this paper also examines the availability of health facilities (public hospitals and drug stores) and the capacity of resources, human resources (doctors and nurses), and health budget resources. The first step of this research is to reduce several documents of the $\mathrm{RI}$ health report, which are then analyzed, then conclude.

\section{RESULT AND DISCUSSION}

During 2000-2018, Indonesia experienced continuous extraordinary occurrences. Launching Indonesia's health information document, several epidemic diseases have a high rate of cases, mainly since extraordinary occurrences have spread in several regions in Indonesia. Cumulatively, the Indonesian government has given the status of this disease outbreak as an extraordinary occurrence. Extraordinary occurrences (KLB) are also referred to as events with a case rate of sufferers with many sufferers of illness and/or death in a short period due to infectious diseases. Incidents of increasing extraordinary occurrences in Indonesia are extraordinary occurrences of diarrhea, dengue fever, and measles. To deal with the outbreak of a disease's extraordinary occurrence, the government considers alternative handling policies. It considers the health sector's budget capacity, the availability of medical personnel and health personnel, and infrastructure facilities (public hospitals and drug stores).

\section{Brief overview of Extraordinary \\ Occurrences Disease in Indonesia}

This section provides an overview of the three major health issue in Indonesia as a foundation to the ensuing discussion of government agility handling it. The review is not exhaustive, but rather selective and intended to describe to what extent the Indonesian government to handling three major issue and its resources management

Extraordinary occurrences that often occur in Indonesia are very diverse. Through our summary of the Health Report by the Ministry of Health of the Republic of Indonesia, from 2000 to 2018, the types of diseases with the highest accumulative morbidity rate were Diarrhea, Dengue Fever, and Measles (see graph 1.1, 1.2, 1.3). Based on this report, this paper aims to analyze the Indonesian government's alternative policies against disease outbreaks that have high morbidity rates, in which the three diseases are often included in the status of sporadic outbreaks of disease in several regions in Indonesia.

Graph 1.1. Diarrhea Morbidity Rate during 2000-2018

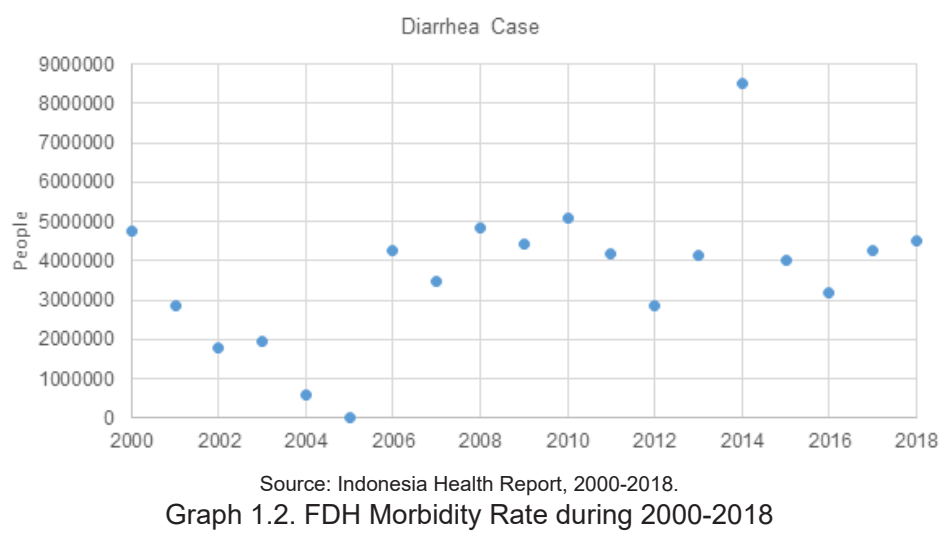




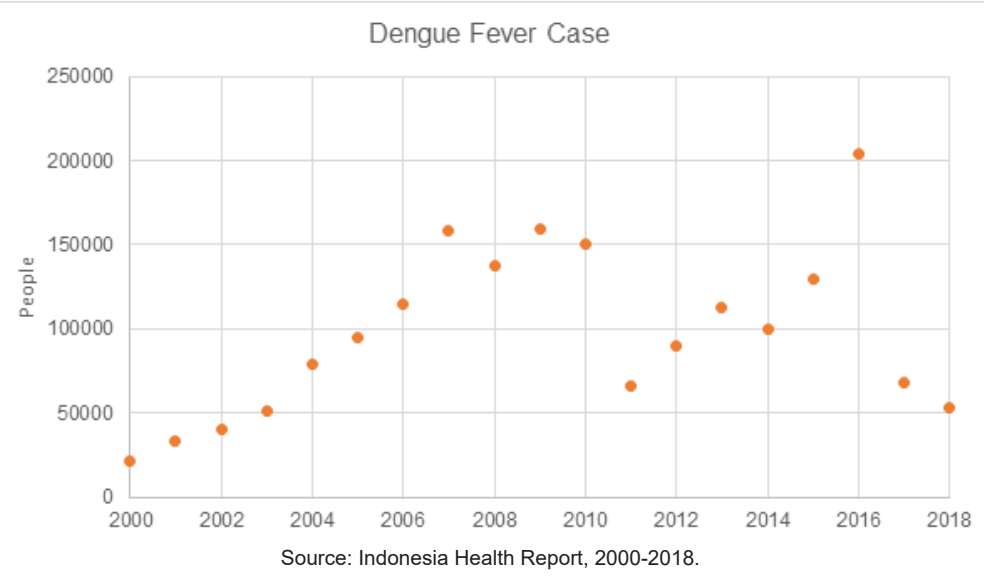

Graph 1.3. Measles Morbidity Rate during 2000-2018

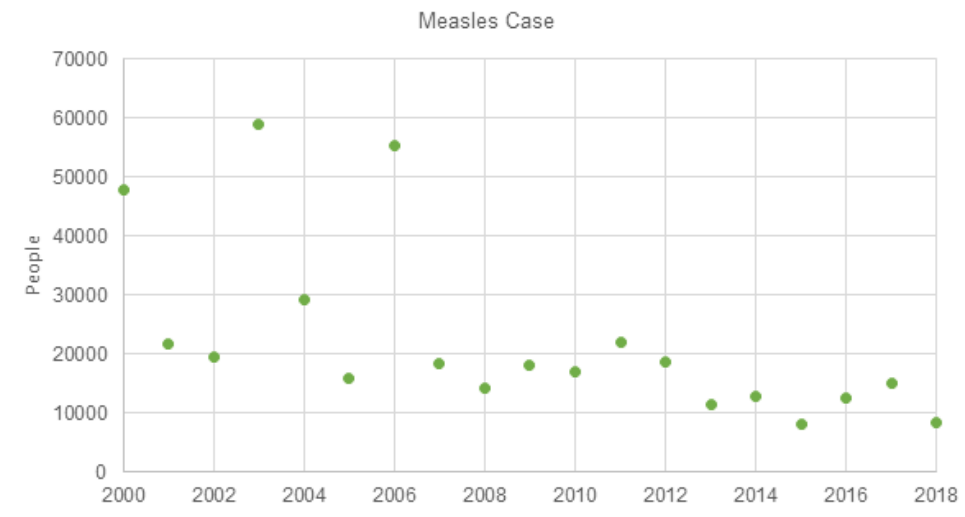

Source: Indonesia Health Report, 2000-2018

Based on the illustration of the data above, facilities and infrastructure to support disease the disease outbreak for Diarrhea cases has the highest sufferers' level. Each year Diarrhea is a type of case that is often the top case of disease outbreaks in several regions in Indonesia. This disease is based on transmission by germs Face-oral route. Furthermore, the Dengue Fever disease outbreak is also a widespread disease with second-highest of cases number of sufferers nationally accumulatively. DHF cause by Aedes Aegypti and Aedes Albopictus mosquitoes. Third, the measles epidemic is an infectious disease epidemic that Indonesians often suffer from airborne transmission by droplets of the other person's breathing (coughing/sneezing), saliva, or skin contact (handshake or hug).

These three disease outbreaks with extraordinary occurrence' status have very high risks and threats, so they require government commitment in making alternative policies for handling the extraordinary occurrences. The government's role is essential in overcoming all disease outbreaks. In addition to making policy alternatives, other things that need to be considered are the budget, distribution of medical and health personnel, and the availability of outbreaks. Some of the indicators above are essential components in resolving the outbreak. As a result, government efforts are critical to saving a person's life during a health crisis.

Although there are efforts to reduce outbreaks through various national programs to control vector spread and morality cases, the fact is that the three diseases (see figure 1.1, 1.2, and 1.3) still show a high enough number and are still occurring in various regions in Indonesia. Therefore, efforts to eradicate this infectious disease outbreak and needs government attention. In general, eradicating infectious diseases can be done through self-awareness efforts, patient discovery, handling of sufferers, eradication of sources of disease, efforts to immunity, and public education. Disease eradication lessons can be learned from cases of previous outbreaks of infectious diseases. So it is necessary to review the epidemic eradication policy because every year, this outbreak still occurs. It is a portrait that the picture of handling infectious disease outbreaks has not been fully achieved. 


\section{Policy Alternative for Diarrhea Outbreak, DHF, and Measles}

First, the diarrheal disease had a high number of cases before the 2000s. For this reason, the Indonesian government issued regulatory provisions through the Decree of the Minister of Health of the Republic of Indonesia Number 1216/Menkes/SK/XI/2001 regarding guidelines for eradicating diarrhea disease. However, since the instruction was decided, the number of diarrhea attendants fluctuated upward so that the government again issued a pocketbook for the 2011 edition of Diarrhea Cross Diarrhea, which stands for (Five Steps to Complete Diarrhea) by administering ORS, administering zinc medication, giving breast/food, giving antibiotics, and giving advice. Implementing the diarrhea control system aims to reduce the level of morbidity and mortality due to the diarrhea disease outbreak. However, in 2014, the number of cases of outbreaks of diarrhea outbreaks experienced the highest spike of 8490976 , the highest number of cases during 2000-2018

Second, controlling the outbreak of Dengue Fever. Although Dengue Fever has the second level of morbidity and mortality, the regulation has been preceded before diarrhea, which was decided in 1992 through the Decree of the Health Ministry of the Republic of Indonesia no 581/Menkes/SK/ $\mathrm{VII} / 1992$ and the regulation has changed. In 1994 through the Decree of the Minister of Health of the Republic of Indonesia no 92/Menkes/SK/II/1994. Considering that the number of dengue fever increased from 2000 to 2007, the government started making a national policy, namely through PSN (Mosquito Nest Eradication). By carrying out the $3 \mathrm{M}$ plus program through the larva monitoring officer (Jumantik), in 2008-2018, the outbreak of Dengue Fever fluctuated with a tendency to decrease even though in 2016 there was a surge in cases of dengue fever sufferers.

Third, the measles epidemic. Measles also cannot be underestimated. In 2003, the number of measles experienced an increase in cases of measles sufferers. Over 2000-2006, the number of Measles cases fluctuated. In 2006, the government issued a policy through the Minister of Health Decree number 552/Menkes /SK/VII/2006. Through this regulation, the government has a commitment to reduce measles cases by carrying out a measles immunization campaign, which is seen (see graph 1.3) in 2007-2018 the number of measles cases has fluctuated decreasing compared to previous years. The National Immunization Program is the mainstay program in immunizing Measles by giving vaccines to reduce cases of morbidity and mortality due to measles.

\section{Financial Ability in the Health Sector}

The budget plays an important role in the process of implementing development - including development in the health sector. By allocating an adequate health budget, it can mobilize the delivery of health services. As a result, by prioritizing a strong and stable budget, the government can control all programs and activities related to the health sector. As for the budget allocation from the ministry of health is the Republic of Indonesia, as follows.

Table 1.1. Annual Budget Allocation in Department of Health, Indonesia

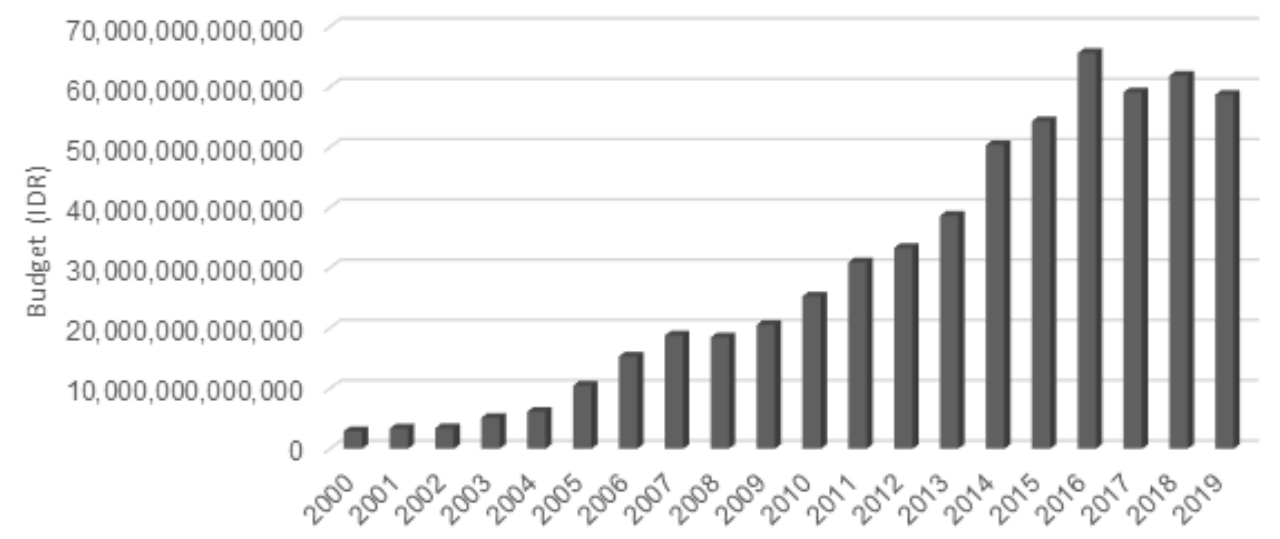

Source: Indonesia Health Report, 2000-2018

Based on the budget of the Ministry of Health of the Republic of Indonesia above, it shows an upward fluctuating budget, in which the 2015 to 2016 budget experienced a quite high increase of IDR. $11,296,263,636,000$ or an increase of $20.80 \%$. If we refer to the highest budget for $2000-$ 2019, then 2018 has the highest budget for the last two decades. However, this budget is the 
total budget for the Ministry of Health, allocated to three levels: the central government budget, the budget for local governments, and the budget for de-concentration. However, 2019 saw a decrease in the health budget allocation, which refers to the year before there was a difference of around 31 trillion. It requires the government's attention in line with the many outbreaks of disease in every region in Indonesia, requiring more health budgets for implementing programs and activities to overcome the spread and control of disease outbreaks and providing salaries and incentives for health workers. As a result, the availability of Graph 1.4 Number of Medical Doctor and Nurses in Indonesia (2000 -2019)

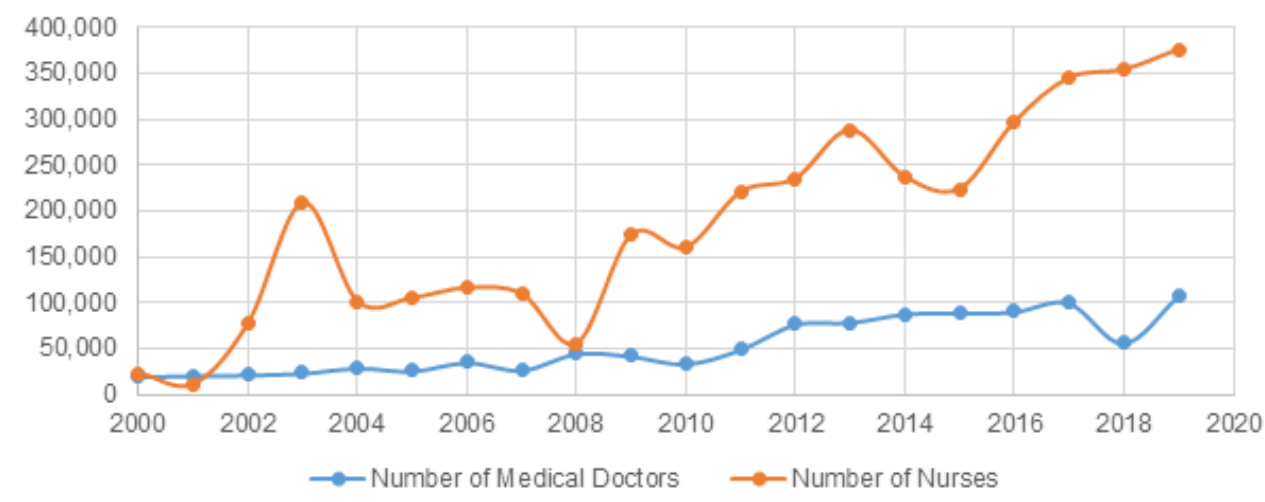

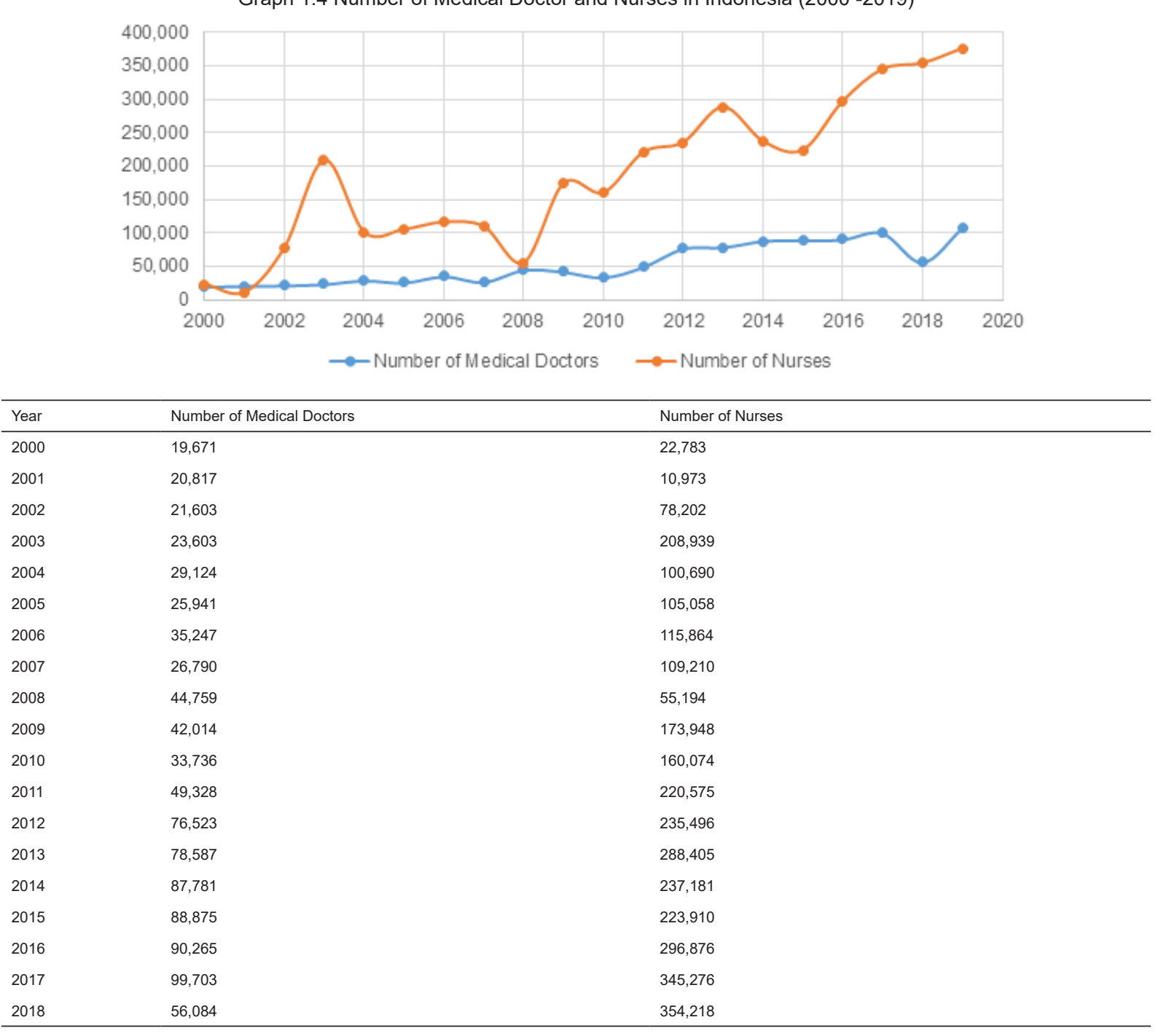

Source: Indonesia Health Report, 2000-2018

The graph above illustrates that the availability of doctors in hospitals in 2019 is 107,007 people, of doctors and nurses is still fluctuating every year. In 2019 the number of medical personnel (doctors) was 107,007 people, and the number of nurses in 2019 was 376,136 people. When Indonesia's total population in 2019 is 267.6 million, and the number an adequate health budget is fair, equitable, and can be useful and channeled according to its allocation.

\section{Availability of medical and health personnel}

Apart from the budget, medical and health personnel's availability in controlling disease outbreaks is essential, and their presence is needed to treat sufferers due to disease outbreaks. Moreover, Indonesia, with its many regions, certainly needs the distribution of medical and health workers. then the ratio of doctors to population in Indonesia will reach $1 ; 2 ; 500$. It means that one doctor can handle as many as 2,500 thousand patients. This ratio is far from ideal. 
Besides, this is not to mention the distribution and distribution of medical personnel in each region. According to the 2018 Indonesian Health Profile document, the distribution of doctors in each province still shows an imbalance in the distribution of numbers. Besides, doctors who have an STR permit do not work according to their function, namely in medical services, resulting in less even distribution of doctors in health care facilities in several provinces. Therefore, to avoid accumulation in one area and be centralized, this requires the government's responsibility to enforce medical personnel's equal distribution in providing services throughout Indonesia.

\section{Provision of facilities \& infrastructure}

Things that need to be considered in supporting the reduction in the number of disease outbreak

Table 1.2 Public Hospital and Drug Stores in Indonesia, 2000-2018

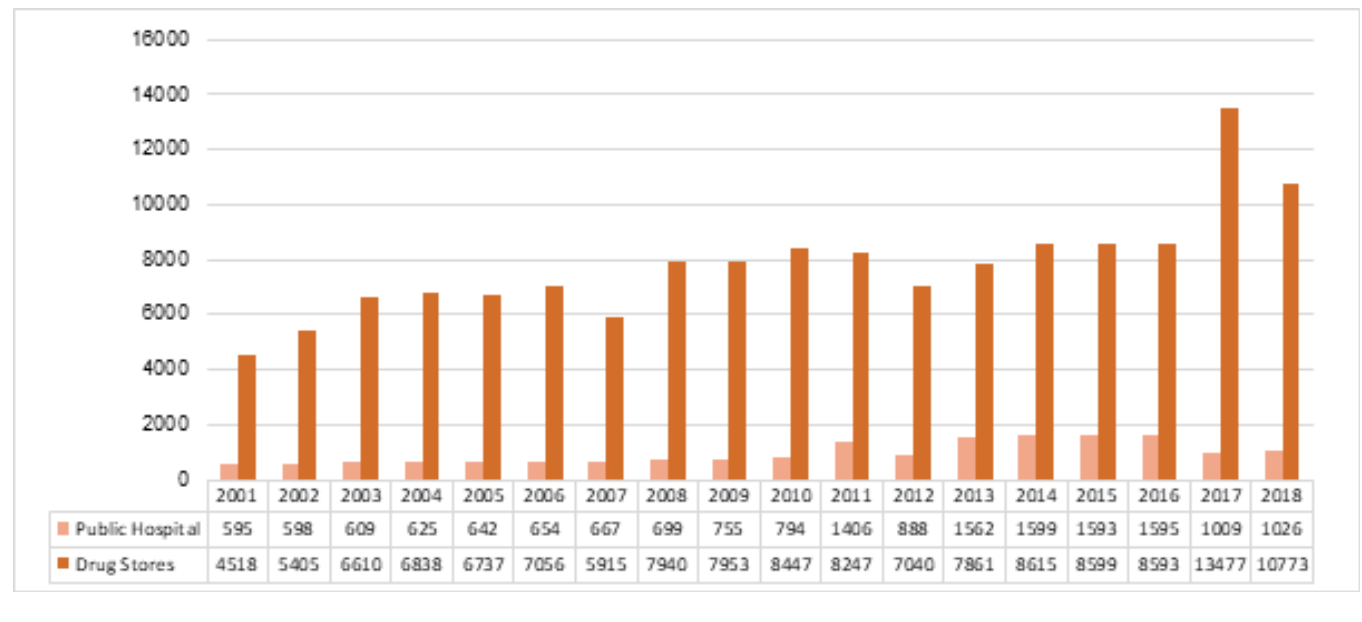

Source: Indonesia Health Report, 2000-2018

Even though government hospitals' growth is not as fast as private hospitals, the growth is quite good. However, the results of our analysis show that the growth of inter-provincial government hospitals is still uneven. According to the 2018 Indonesian Health Profile document, the ratio of healthcare facilities' distribution uneven, such as hospitals and drug stores. As the significance of hospitals' growth is only in some regions 1 (one), meaning that it is increasing aggressively compared to other regions where the growth is not too significant. The growth of public hospitals is more in regional 1 with an average growth of $15 \%$, while the growth outside these regions is not very significant. That is, centralism still occurs and is still very strong in the construction of public hospitals. Meanwhile, monitoring the spread of disease outbreaks with the status of Extraordinary Events is often experienced outside of regional 1.Thus, and it requires a commitment from the sufferers are hospital facilities and drug stores' availability. These tools have significance in dealing with the spread of disease outbreaks because the hospital is a place of care for patients with a severe disease outbreak, and a drug store as a supply of medicines for those who need a prescription. So that hospitals and drug stores play an important role in handling disease outbreaks. Based on the Republic of Indonesia's health report document, the growth in the number of public or government-owned hospitals is not as fast as the growth of private hospitals, the average growth of public hospitals is $0.4 \%$ compared to private ones of $15.3 \%$. The number of government hospitals and the growth of drug stores in Indonesia is as follows. government to even out the growth of hospitals in all regions in Indonesia.

Overall, various government policies in handling disease outbreaks with outbreak status are still ongoing. Even though the number of cases of disease outbreaks has decreased fluctuating, it still tells of the number of sufferers with a high number. Besides, the limited health facilities in some areas and the availability of medical and health personnel are still minimal, and their unequal distribution in some areas is a factor in inequality. In providing community services and allowing the quality of service to be less than optimal, alternative policies for handling outbreaks of disease outbreaks are still lacking, such as diarrhea, which only provides a cross-diarrhea program, without any priority for vaccines. Furthermore, to overcome the problem of Dengue Fever, it is not enough to carry out the $3 \mathrm{M}$ plus program through its Larva Monitor (Jumantik), but it requires new programs and breakthroughs. 
Finally, in eradicating the measles outbreak, the National Immunization Program is considered to have worked well, as illustrated in the measles outbreak (see graph 1.3). However, we think that measles immunization is not sufficient to complete the target of eliminating disease outbreaks shortly. Therefore it requires other policy alternatives so that this outbreak can be resolved immediately upon its spread.

Besides, the distribution of medical and health personnel is still a fundamental problem. The centralized distribution is only on the island of Java, resulting in a shortage of medical personnel and health personnel outside Java. Given that most outbreaks of diarrhea, dengue, and measles are experienced outside Java, it is challenging for the government to distribute it evenly to all provinces - including outbreaks that often occur every year. Apart from distribution, training, and dissemination of disease outbreak prevention require serious attention. There are still Indonesians who do not understand prevention measures and efforts to deal with disease outbreaks. It means that the government must be able to provide justice for all regions in Indonesia. Another issue regarding the budget is very vital. The allocation and distribution of the health budget from the Ministry of Health still require outside funding because there is still a lack of budget for handling the epidemic, plus the budget is divided into three levels of government in funding. In line with this problem, government hospitals' development requires attention for the government, especially the construction of hospitals in areas outside Java, so that all can experience equality and equal opportunities in health services.

\section{CONCLUSION}

This paper does not consider outbreak diseases analysis - our study focuses on alternative policy on outbreak diseases and how the government considers alternatives to dealing with the diseases. Additionally, this paper intends to analyze the health financial abilities, facilities (public hospitals and drug stores), and human resources (doctors and nurses). In conclusion, several outbreaks of disease outbreaks - including outbreaks of diarrhea, dengue, and measles, still need alternative policies that can deal with the outbreaks as soon as possible by considering the successes and failures of previously implemented policies. Based on the Diarrhea Outbreak Policy, it requires additional policies in handling the diarrhea outbreak, not only relying on the Cross Diarrhea program, but it also requires breakthroughs in handling it. Second, the DHF outbreak relies not only on the 3M program through a larva monitoring officer (Jumantik).
Although sufferers' cases fluctuate in decline, the government needs further studies to be able to eliminate the occurrence of dengue outbreaks in the future. Finally, for the Measles Outbreak, the National Immunization Program is rated as a mainstay program in immunizing Measles by giving vaccines as an effort to reduce cases of morbidity and mortality due to Measles, so this needs better efforts so that it can function in the future with consistent vaccine programs there is a breakthrough for the elimination of Measles so that it continues to decrease drastically.

Also, to support public health achievement, the government must further concentrate on the health of its budget. Besides that, the availability of facilities in several regions must prioritize equality according to needs, and finally requires an even distribution of medical personnel and health workers. We think that the availability of health facilities and the distribution of resources are critical aspects in supporting the creation of good health governance sustainably.

\section{REFERENCES}

1. Arlinda, S. (2019). Perilaku Sanitasi Sebagai Penentu Kejadian Diare Pada Anak Di Indonesia. Buletin Keslingmas, 38(4), 358364. https://doi.org/10.31983/keslingmas. v38i4.5500

2. Arsyad, R. M., Nabuasa, E., \& Ndoen, E. M. (2020). Hubungan Antara Perilaku Sanitasi Lingkungan Dengan Kejadian Demam Berdarah Dengue (DBD) Di Wilayah Kerja Puskesmas Tarus. Media Kesehatan Masyarakat, 2(2), 15-23. https://doi.org/ https://doi.org/10.35508/mkm

3.Badan Pusat Statistik. (2018). Indikator Perumahan dan Kesehatan Lingkungan Tahun 2018. Jakarta.

4.Baxter, P., Susan Jack, \& Jack, S. (2008). Qualitative Case Study Methodology: Study Design and Implementation for Novice Researchers. The Qualitative Report Volume, 13(4), 544-559. https://doi. org/10.2174/1874434600802010058

5. Isidore, K. K. (2011). Eradicating Measles Outbreaks in Refugee Camps. Retrieved December 12, 2020, from United Nations University website: https://unu.edu/ publications/articles/eradicating-measlesoutbreaks-in-refugee-camps.html

6. Jones, G.W.(2014). The2010-2035Indonesian Population Projection: Understanding the Causes, Consequences and Policy Options for Population and Development. In UNFPA. Jakarta.

7.Jong, W. de, Rusli, M., Bhoelan, S., Rohde, S., 
Rantam, F. A., Noeryoto, P. A., ... Goeijenbier, M. (2018). Endemic and emerging acute virus infections in Indonesia: an overview of the past decade and implications for the future. Critical Reviews in Microbiology, 44(4), 487-503. https://doi.org/10.1080/104084 1X.2018.1438986

8. Palang Merah Indonesia. (2015). Epidemic preparedness in Indonesia. In International Federation of Red Cross and Red Crescent Societies.

9. Pertiwi, K. D., Mirnawati, Laila, O. N., \& Putra, A. (2019). Pendampingan Pemberantasan Vektor Demam Berdarah Dengue (DBD) pada Kelompok Ibu Rumah Tangga di Desa Gebugan. Indonesian Journal of Community Empowerment (IJCE), 1(2), 43-45.
10. Ridder, H. (2017). The theory contribution of case study research designs. Business Research. https://doi.org/10.1007/s40685017-0045-z

11. Worldometers. (2020). No Title. Retrieved December 12, 2020, from Worldometer elaboration of the latest United Nations data website: https://www.worldometers.info/worldpopulation/indonesia-population/ 